\title{
次こそ生かす！臨床医に必要な病理とは？
}

\author{
川上茂久 \\ 群馬サファリパーク テ 370-2321 群馬県富岡市岡本 1 番地

\section{What is the Pathological Anatomy Necessary for Clinical Veterinarians that be Going to Make the Best Use in the Future?}

\author{
Sigehisa KAWAKAMI \\ Gunma Safari Park, 1 Okamoto, Tomioka, Gunma 370-2321, Japan
}

\begin{abstract}
The pathologic anatomy elucidates the individual cause of death and gives much information, check of the quality of the treatment, and simulation of the surgical operation for clinical veterinarian. Furthermore, we think that the keeper should participate in pathologic anatomy. Because it can make use of the cause of animal's death on husbandry and improvement in nutrition. However, the clinical veterinarian may not have a lot of time that is enough for pathologic anatomy. This report introduces clearly macroscopic observation, systematic pathologic anatomy to sampling. In reference to this procedure, we want significant pathologic anatomy to carry out by safety in consideration of zoonosis.
\end{abstract}

Key words : pathologic anatomy, clinical veterinarian.

Jpn. J.Zoo. Wildl. Med. 16 (1) : 9-13, 2011

\section{はじめに}

臨床医の病理解剖学は, その個体の死因だけでなくその結果 によって治療の良否, 動物飼育管理や栄養の改善点までも明ら かになることがある。海外では, 動物園の中に病理医を置いて いるところもあるが, しかし, 日本の動物園臨床医の日常業務 の中で臨床病理に時間を割くことは, 非常に難しいことである。 その中でより良い臨床病理を進めるために実践を通じて考えて きたことは, 本来の病理では, 全身の剥皮, 開腹, 開胸, そし て臓器の摘出, 肉眼的観察, サンプリングなどである。しかし ながら, 臨床医にとってこの過程を病理学的手順にそって行う には，時間的束縛がある。

群馬サファリパークでは, 群馬方式と呼んでいる臨床病理解 剖の基本プロセスを行っている。例えば，日常業務と病理解剖 の兼ね合いで, 最低必要な日常業務終了後に速やかに病理解剖 を行う。遺体の保管原則は, 日陰, 冷蔵庫などに移動し, 移動 困難な場合は $6 \sim 12$ 時間以内に病理解剖を行う。獣医と飼育 の作業分担は, 獣医が臓器を取り扱い飼育は, 筋肉や骨を担当 する。解剖チームのルールは, 遺体の生前の臨床を理解してい る獣医がリーダーとなり解剖チーム全員が異常を発見した場合 リーダーに必ず報告するなどである。究極のルールは, 脳の摘 出以外すべて解剖刀で行う, これが臨床医にとって「次こそ生
かす!」原点である。

各臨床医にとって実践可能なより早い, より良い肉眼的観察, サンプリングの方法が参考になり今後の臨床病理に参考になれ ば幸いである。

最後に, 素晴らしい病理学者と出会えた私が, 病理に貢献で きるのは, その病理学者の真摰な姿勢を拝見し, 個々の臨床病 理の中で直接お話を聞けたことです。是非, 皆様が良き病理学 者と出会えることを期待しています。そして, お互いが, 望ん でいることを遠慮なく意見交換ができることは, より良い臨床 病理が発展していく道だと考えている。

\section{病理解剖実施にあたり}

病理解剖は, 死後 $6 \sim 12$ 時間以内に病理解剖を行う必要が ある。夏季は, 自己融解の進行が早いため, 小・中動物は, 冷 蔵庫で保存する。大動物を入れる冷蔵庫はなかなかないので, できるだけ早く（3〜 6 時間以内）に病理解剖を行うべきであ る。日常業務は最低限にして, 病理解剖の時間を割くよう飼育 と獣医の時間調整し, 病理解剖のスケジュールを立てる。解剖 を行う前には, 過去の病歴を調べておく。特に人獣共通伝染病 の可能性に注意し, 解剖時の体制を考える。過去に 1 度だけ, 安全を重視し, 解剖を行わなかったことがある。真夏で解剖ま で時間かかったため自己融解が進行し, 気腫疽様を呈していた 
ときである。感染拡大, 解剖に関わる者の安全性を十分に考慮 し, 解剖計画を行って欲しい。

\section{病理解剖体制の計画}

獣医師それぞれが，各臟器を別々にみていると全体像が分か らなくなってしまう。そこで, 最初に獣医師の中でリーダーを 決める。リーダーは, 個体の病歴を十分に理解し, 個体に強い 思い入れをしていない者を選ぶ。個体に深い思い入れがあると， 客観的な判断ができず，生前の疾患にとらわれるため，真の病 因を見落とすことがあるからである。また，飼育員も病理解剖 に参加すべきである。飼育員は, 動物解剖学, 病理学に触れる ことにより，動物の死因を日常の飼育に生かすことができる。

当園の解剖は, 獣医師は臓器を担当し, 飼育員は, 筋, 骨, 皮膚を担当する。しかし, 全ての情報は, リーダーに伝達し, 処理の方法を必ず確認するようにしている。また，記録係は， 筆記係, カメラ係とビデオ係でそれぞれ 1 名ずつがいること が理想である。解剖に必要な道具は，以下の通りである。

・解剖刃

・砥石，ヤスリ

・ロープ（各サイズ，各長さ)

・チェーンブロックまたは重機（大動物）

・吊り帯

・メス，ナイフ，ピンセット（臟器採取用）

・10\%ホルマリン，90\%アルコール

・ディスポーザブルのグローブとマスク

・軍手

・メジャー

・体重計

・筆記用具，カメラ，ビデオ

\section{病理解剖実施の注意点}

作業は，知恵を出し合い，互いに声を掛け合い，全てをリー ダーに確認し, リーダーの指示に従って行う。必要な臟器と 必要でない臓器を分けて分担して行うとスムーズな作業が進行 する。近くで 2 名以上の者が同時に解剖刃を使用すると危険 である。安全のため, 必ず部位ごとに離れたところで作業すべ きである。重機などで，吊るし解剖は，体が楽で作業がしやす いが，切断時に「落ち込み」や「振られ」があり，事故につな がることがある。十分に注意して行って欲しい。ロープワー クで滑車がない場合は，南京結び（トラック結び）を応用する と重いものを容易に引き上げることができる。

\section{群馬サファリ式病理解剖}

では，具体的な方法を説明します。まず，前肢，後肢を同時 進行で切除する（図 1）。大動物の解剖など重機を使うときは, ロープの縛り方に注意しなければならない。普通の縛り方で は，硬くなり解けなくなる。徳利結びが最善の方法である。切 除した前肢, 後肢は, 絵別の場所に移動し, 解剖を続ける。胴 体は，皮膚を腹部正中線から背線部まで剥皮する（図 2）。腹 壁を最後肋骨に沿って腹腔まで切開する。このとき，腸管を切 らないように最後胁骨の腰部に刃を入れ，その後，そこに解剖 刃の柄を入れて解剖刃の握り部分の上を使って切開するのがコ ッである。正中線, 後腹部, 背部は, 腹壁を持ち上げて切開し, 腹壁を切除する（図 3）。胁骨を胸椎と胸骨から外す（図 4）。 この段階で, 胸腔臓器, 腹腔臓器の位置関係, 大きさなど全体 を観察する。アフリカスイギュウの場合，肋骨が重なっている ので，肋骨を外すとき，邓を胁骨間に水平に入れなければなら ない。ゾウの場合, 肺と胸膜がくっついているため, 胸膜の剥

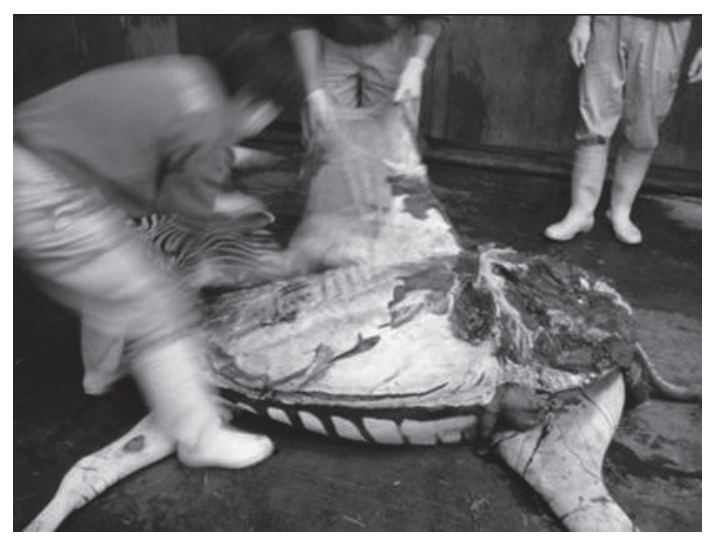

図 2 チャップマンシマウマの皮膚を皮下剥離

図 1 アフリカゾウの前肢を切除 
離が大変である。腹腔内の臟器を先に摘出後, 肋骨を外した方 が作業の進行が早い。

次に各臟器の摘出を行う（図 5)。摘出した臓器は, それぞ れ表面および割面, 内腔を観察する。ゾウなどの蔵器は大きく, 蔵器の $90 \%$ が正常でも $10 \%$ に病変が見つかることがある。図

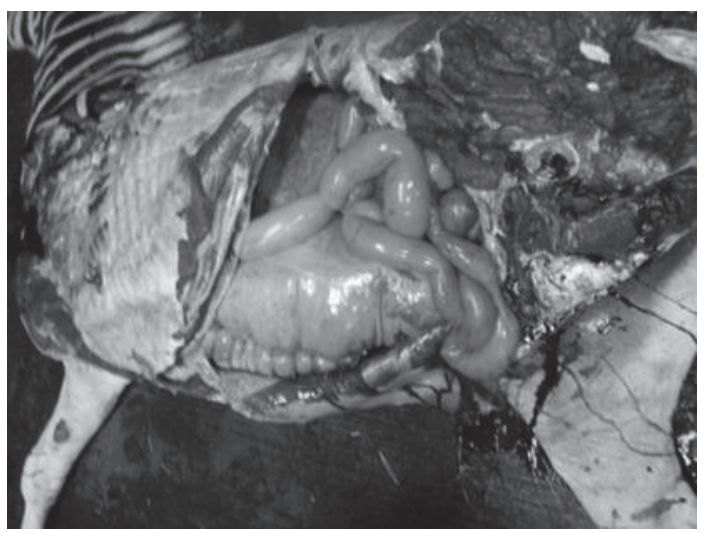

図 3 チャップマンシマウマの腹壁の切去

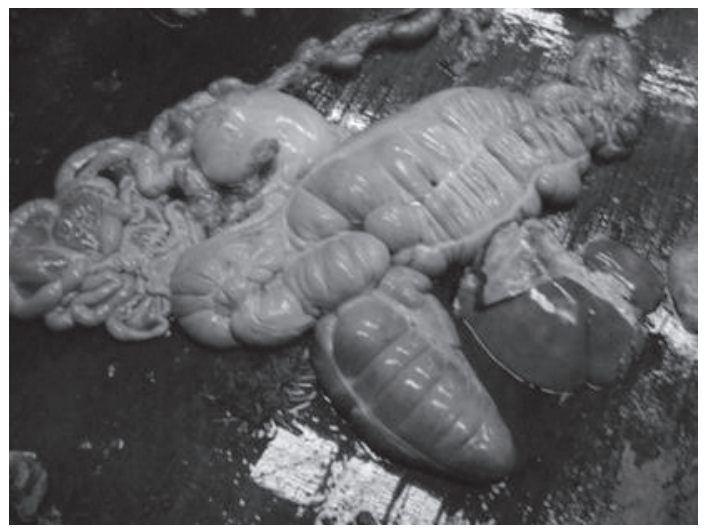

図 5 チャップマンシマウマの内臟摘出

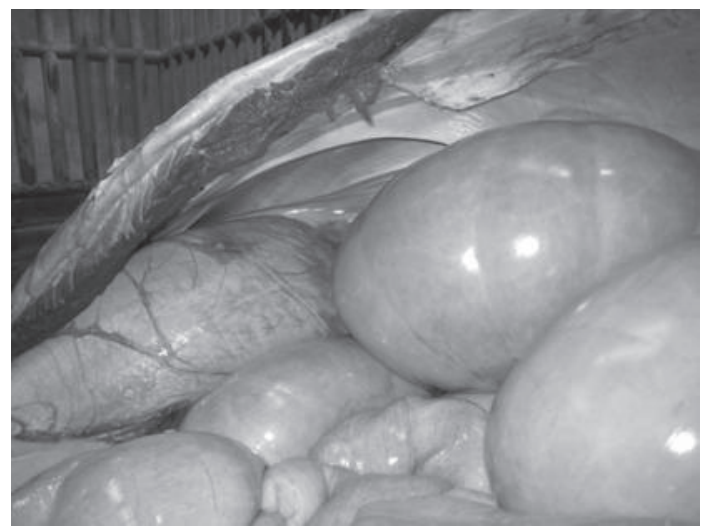

図 7 アフリカゾウにおける胃と横隔膜の癒着
6 のように大型獣の臟器は 5 〜 $10 \mathrm{~cm}$ 間隔で割面を入れるとよ い。このときの留意点は, 胞膜 1 枚残す。切断してしまうと後 でどの部位か判明しなくなるからである。病変部は, 正常部と 異常部を含むように採取し, 病理組織検査に送る。各藏器を摘 出後, 反転して前肢後肢の分断を行う。頭蓋骨と頚椎, 胸椎と

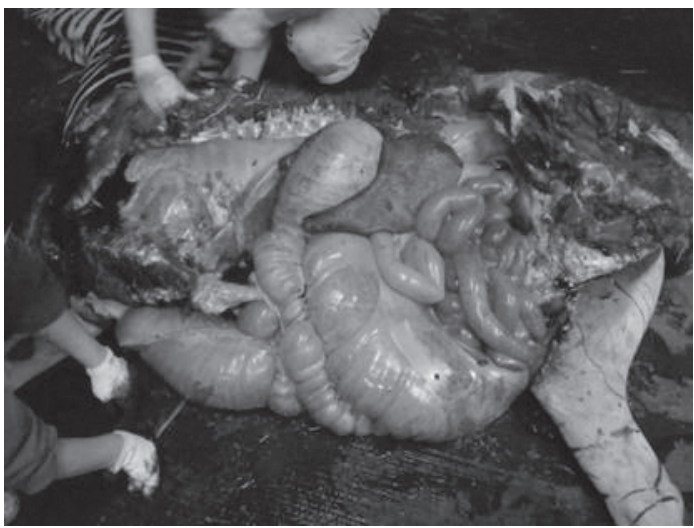

図 4 チャップマンシマウマの胸壁の切除

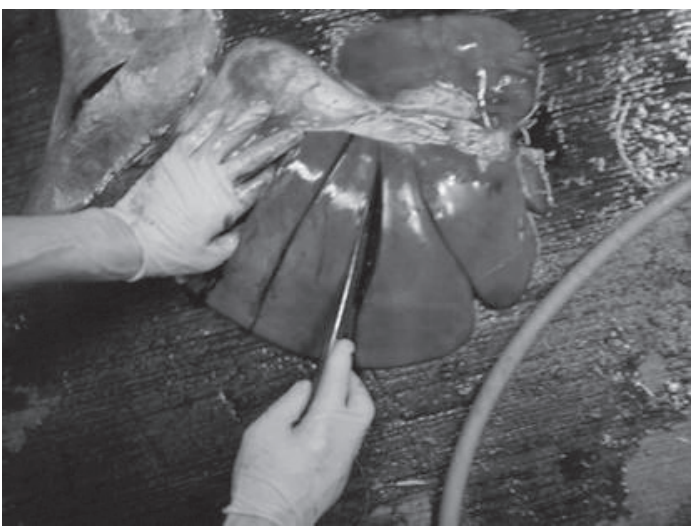

図 6 チャップマンシマウマの肝臟切開

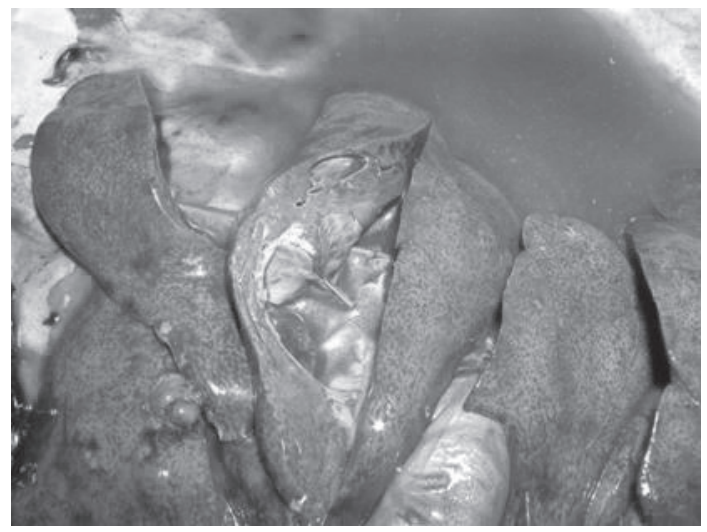

図８アフリカゾウの肝臓。肝空砲が観察される。 


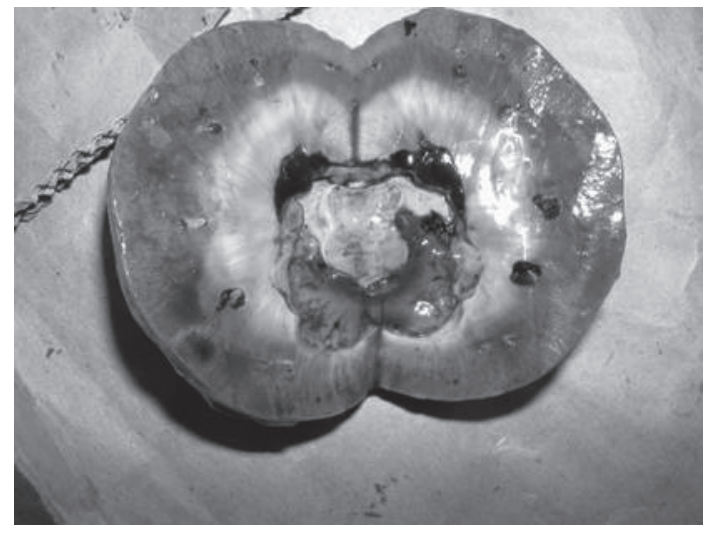

図 9 アフリカゾウの腎臓。出血が観察される。

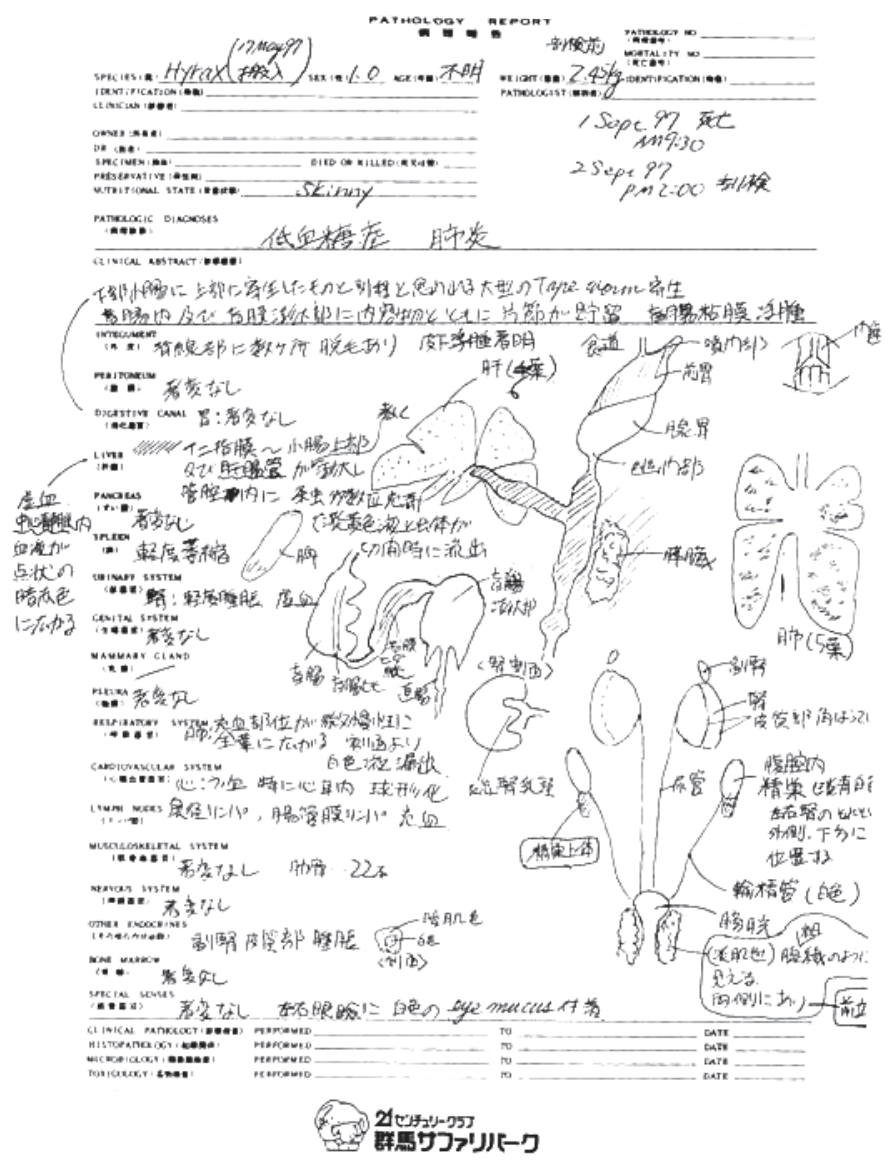

図 11 群馬サファリパークの解剖診断書

腰椎で分断すると後処理が容易である。

ご紹介した当園の方式の利点は, 癒着, 捻転, 全臟器の大き さ色彩が同時に観察できることである。いくつかの臟器病変例 を紹介する。

図 7 は, ゾウ腹部である。胃の裏側が横隔膜と癒着してい

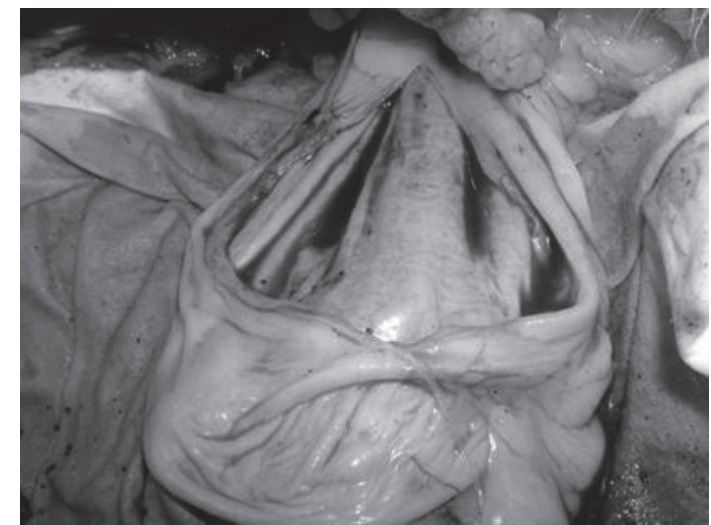

図 10 アフリカゾウの膀胱。血尿貯留が観察される。

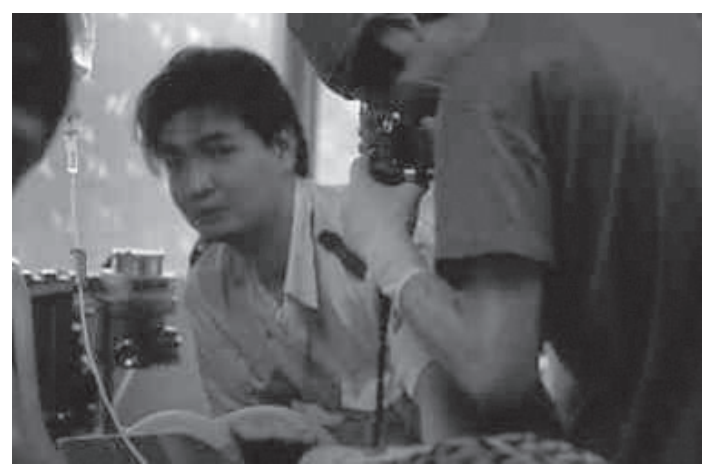

図 12 内視鏡によるチーター胃壁の生検

るため, 胃が異常に横隔膜方向に引つ張られている。図 8 は, ゾウの肝臓である。外見は, 異常な形を呈し, 切開すると肝空 胞があった。解剖時に五感を使い正常臓器を覚えることも重要 である。正常を知ることで, 異常な色, 硬さ, 艶, 形, 臭い, 臓器のテンションのかかり方が分かる。腎臟に出血がある場合, 血尿がみられる。腎臓と同時に膀胱も確認する必要がある（図 9, 図 10)。また, 膵臟に異常がある場合, 十二指腸開口部と腸, 近縁のリンパ節に病変がある可能性があるので, 一緒にサンプ リングする。このように, できるだけ系統だった解剖, 臟器の 検査をするべきだと考える。

\section{記 録 方 法}

記録を残すことは, 解剖を行うこと同様に重要である。図 11 は, 本園館の病理報告書です。特徴は, 記録紙に枠がない ことである。枠がついている病理報告書は, 枠内に入れるため に書き落としが多くなる。病変がない場合も「著変なし」と記 入する。後日, 見直したとき, 何も書いてないと, 見たが変 化がなかったか, 見なかったのか分からない。書いてないこと は, 思い出せない場合が多いので必ず記入すること。気になる 


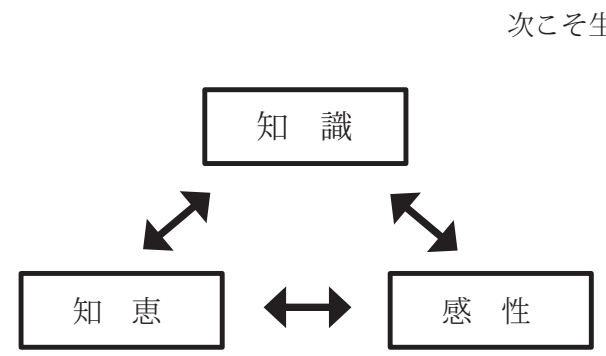

図 13 臨床獣医師の 3 大要素

点は, 図を手書きで残すことをお勧めする。解剖時の状況を復 習し, より理解することができる。また, 数年後に見直しても そのときの様子が, 思い出しやすくなる。写真を撮った場合は, 「写真あり」と記述し，番号も記せば，見直すのが容易である。

\section{今後の臨床病理}

臨床医にとって動物の治療が重要であることはいうまでもな い。今後, 野生動物臨床医は, 生検の技術を磨いていく必要を 強く感じている。チーターは腎疾患同様に胃炎の罹患率が多い ことが知られている [1-3]。胃炎の主な原因は, ヘリコバクター で, 内視鏡による生検よる診断が可能である $[4,5]$ 。当園で も麻布大学獣医病理学研究室の宇根教授協力のもと, チーター 胃壁のサンプリングを行った（図 12）。採取された細小の組織 からヘリコバクターの培養, 動物摂取法による診断を行った。 今後, 野生動物分野においても生検による病理学的診断が発展 することを願っている。

\section{最後に}

病理解剖方法について述べてきたが, 病理解剖が与えてくれ る知識と技術は，それだけに留まらない。病理解剖は，脳の摘 出以外, 全てを解剖刃で行っている。実は, それが, 外科手術 のシュミレーションや局所解剖の基礎になるからだ。病理解剖 は, 外科だけでなく, 内科や飼料, 行動, 形態, 進化について 解明できるチャンスでもある。臨床医 1 人で, この全てを行 うことは, 困難であるが, 研究者などのプロフェッショナルの 方々と共同すれば可能である。病理解剖のたびに, 新しい知見
が生まれる可能性を秘めている。

知識は, 本, 文献, 専門書で得られる。知恵は, 過去の経験 や先人の経験の中から学べ, 応用できる。感性は, 物を見る目, 触った感触, 臭いなど経験で養える（図 13）。臨床や病理解剖 は, 以上の 3 点を総合して行う。本発表が皆様の知識, 知恵, 感性の肥やしになれば幸いである。

\section{要 約}

病理解剖は, 個体の死因を明らかにし, 治療の良否, 外科手 術のシュミレーションなど臨床獣医師にとって多くの情報を与 えてくれる。また，飼育員も病理解剖に参加すべきと考える。 動物の死因を飼育管理や栄養の改善に生かすことができるから である。しかし，臨床獣医師は病理解剖に十分な時間を割けな いことがある。本稿では, 的確な肉眼的観察, サンプリングを 行うための体系的な病理解剖を紹介する。本手順を参考に，人 獣共通伝染病などを考慮し, 安全で有意義な病理解剖を行って いただきたい。

キーワード : 病理解剖, 臨床獣医師

\section{参 考 文 献}

1. Munson L, Nesbit JW, Meltzer DG, Colly LP, Bolton L, Kriek NP. 1999. Diseases of captive cheetahs (Acinonyx jubatus jubatus) in South Africa: a 20-year retrospective survey. J Zoo Wildl Med. 30: 342-347

2. Munson L. 1993. Diseases of captive cheetahs (Acinonyx jubatus): Results of the cheetah research council pathology survey, 1989-1992. Zoo Biology 12: 105-124

3. Munson L, Terio KA, Worley M, Jago M, Bagot-Smith A, Marker L. 2005. Extrinsic factors significantly affect patterns of disease in free-ranging and captive cheetah (Acinonyx jubatus) populations. J Wildl Dis. 41: $542-548$

4. Lane E, Lobetti R, Burroughs R. 2004. Treatment with omeprazole, metronidazole, and amoxicillin in captive South African cheetahs (Acinonyx jubatus) with spiral bacteria infection and gastritis. J Zoo Wildl Med. 35: 15-19

5. Wack RF, Eaton KA, Kramer LW. 1997. Treatment of gastritis in cheetahs (Acinonyx jubatus). J Zoo Wildl Med. 28: 260-266 